\title{
Hydrogeomorphological Study in Bamanghaty Subdivision of Mayurbhanj District, Odisha an Integrated Remote Sensing and GIS Approach
}

\author{
Debabrata Nandi ${ }^{*}$, Pramod Chandra Sahu ${ }^{2}$, Shreerup Goswami ${ }^{3}$ \\ ${ }^{1}$ Department of Remote Sensing and GIS, North Orissa University, Odisha, India \\ ${ }^{2}$ Department of Geology, MPC Autonomous Colleges, Baripada, Odisha, India \\ ${ }^{3}$ Department of Earth Science, Sambalpur University, Sambalpur, Odisha, India \\ Email: *debabrata.gis @gmail.com
}

How to cite this paper: Nandi, D., Sahu, P.C. and Goswami, S. (2017) Hydrogeomorphological Study in Bamanghaty Subdivision of Mayurbhanj District, Odisha an Integrated Remote Sensing and GIS Approach. International Journal of Geosciences, 8, 1361-1373.

https://doi.org/10.4236/ijg.2017.811079

Received: October 10, 2017

Accepted: November 24, 2017

Published: November 27, 2017

Copyright () 2017 by authors and Scientific Research Publishing Inc. This work is licensed under the Creative Commons Attribution International License (CC BY 4.0).

http://creativecommons.org/licenses/by/4.0/

\begin{abstract}
Remote Sensing (RS) and geographic information system (GIS) are now very essential tools for efficient planning and management and handling a range of data simultaneously in a time- and cost-efficient manner for targeting of groundwater, which assists in measuring, monitoring, and conserving groundwater resources. Survey of India toposheets, LISS-III and CARTOSAT DEM satellite imageries are used to prepare various thematic layers viz., geology, slope, lineament, drainage, and geomorphology, and were transformed to raster data using feature to raster conversion tool in ArcGIS spatial analysis, then we reclassify each raster map using reclassify tools. By using weight overlay analysis, each weighted thematic layer is statistically computed to get the ground water potential zones. Then, five different groundwater potential zones were identified, namely "very good", "good", "moderate", "poor", and "very poor". The villages under poor groundwater potential zone and the villages under very good groundwater potential zone are finding out. The above study has clearly demonstrated the capabilities of Remote Sensing and GIS in demarcation of the different groundwater potential zones in hard rock terrain.
\end{abstract}

\section{Keywords}

Hydrogeomorphology, Remote Sensing, GIS

\section{Introduction}

Now a day, the most important issues are faced by the society i.e. high population growth, fast urbanization and climate change along with the irregular rate and intensity of rainfall and its impact on the availability of water. In Semi-arid 
country like India, $65 \%$ of area is under hard rock formation with low porosity and very low permeability. The surface water is not available throughout the year for various purposes. So, it is essential for the proper management of both surface and groundwater resources by systematic inventory, conservation and proper planning for economic and social development. The occurrence and distribution of groundwater is depending by several factors such as lithology, geological structures, Geomorphology, Soil structure, slope, drainage pattern, drainage density, landforms, land use/land cover, climatic conditions and interrelationship between them [1] [2] [3]. The Remote Sensing and GIS are essential tools for identification of ground water potential, because it gives multi Temporal, multi spectral and multi resolution with multi sensor data of a target area which we are interested [4]-[11]. In the past, several researchers have used RS and GIS techniques for the delineation of groundwater potential zones [12] [13] [14]. During the present investigation, the study was conducted to find out ground water potential zones in Bamamghaty Subdivion of Mayurbhanj district, Odisha by integrating various thematic maps in GIS environment such as geology, geomorphology, soil texture, land use/land cover, drainage, lineament map was prepared for the study area. The groundwater potential zones were obtained by overlaying all the thematic maps in terms of weighted overlay methods.

\section{Study Area}

The learning area of Bamanghaty is one of the remote sub-division of Mayurbhanj district of Odisha state. Bamanghaty Subdivision is one of the four subdivisions of Mayurbhanj, the biggest district of Odisha. The study area is the part of Chota Nagpur plateau of Precambrian Geology. The study area is very important for the Hydrogeomorphic and Geohydrologic Groundwater maintenance and potentialities. It is an incurable part of Chota Nagpur Plateau. The subdivision extends between $85^{\circ} 55^{\prime \prime} \mathrm{E}$ to $86^{\circ} 30^{\prime \prime} \mathrm{E}$ longitude and $22^{\circ} 0^{\prime \prime} \mathrm{N}$ to $22^{\circ} 35^{\prime \prime} \mathrm{N}$ latitude (Figure 1). It is surrounded by Singhbhum district of Jharkhand in North and West, Panchpir Subdivision in South and Baripada Subdivision in the East

\section{Methodology}

The Hydrogeomorphic study of Bamanghati Sub-Division of Mayurbhanj, Odisha has been used the multiple data for the Field examination and creation of map by the Remote sensing techniques. Then collection of data has been used i.e. BHUVAN data, Survey of India Toposheet (73J/2, 73J/3, 73J/4,73J/7,73J/8, $73 \mathrm{~F} / 14,73 \mathrm{~F} / 15,73 \mathrm{~F} / 16,73 \mathrm{~K} / 1$ ) Landsat Oli data, Primary data and Secondary data. The slope map was prepared from CARTOSAT DEM data. The drainage density and lineament density maps were prepared using the line density analysis sub tool of Spatial analysis tools in Arc GIS tool box. After preparing thematic map, all map was compile together in Weight overlay sub tool of spatial analysis tool in Arc GIS. Different weight and rank is given to each thematic map according the ground water occurrence. Cumulative Score Index (CSI) was used 


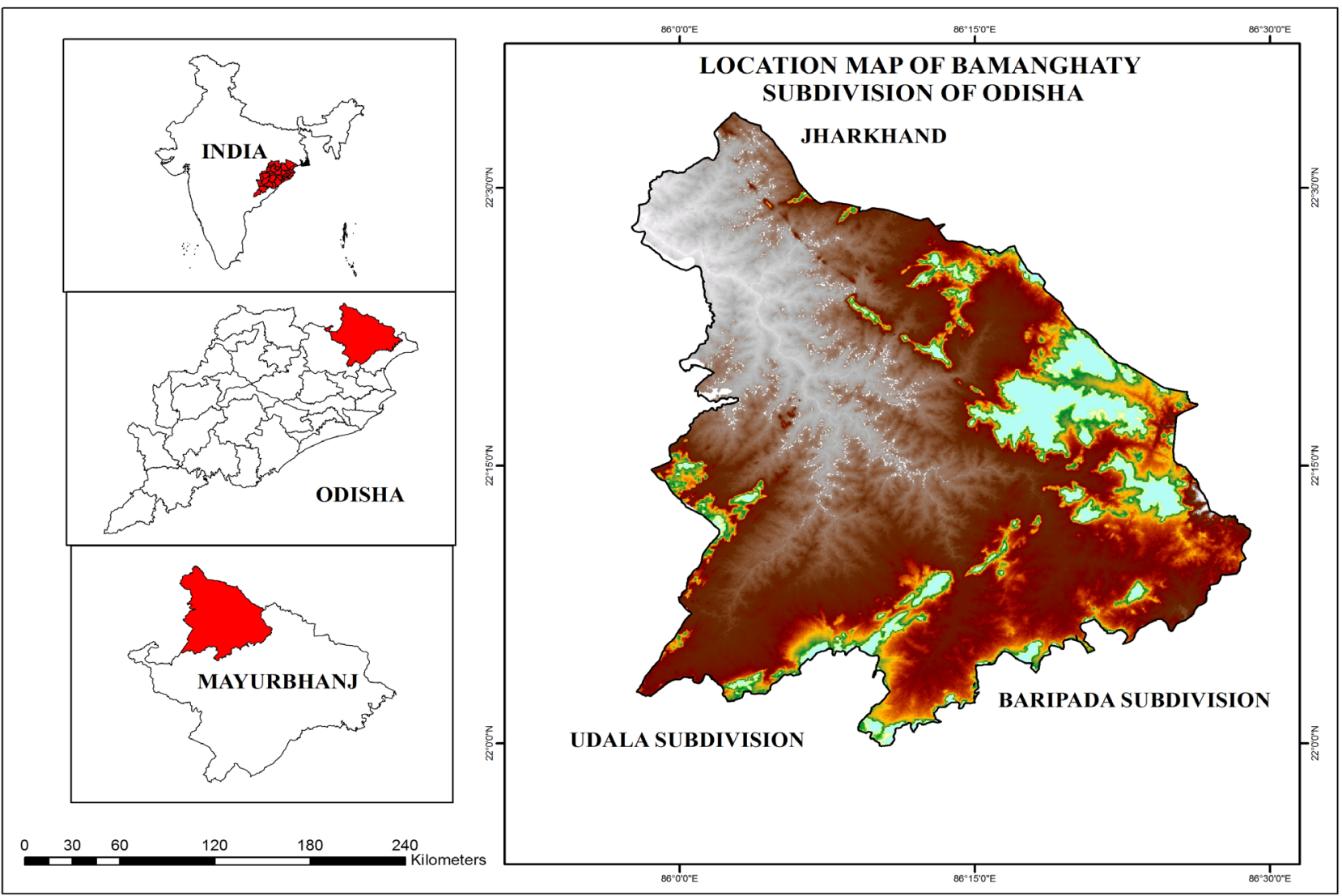

Figure 1. Location of the study area.

for this classification. CSI was calculated by multiplying the rank and weightage of each thematic as mention in the below:

$$
\begin{gathered}
\text { CSI }=\sum(\text { Geology rank } \times \text { weight }+ \text { Geomorphology rank } \times \text { weight } \\
+ \text { Soil rank } \times \text { weight, Lineament density rank } \times \text { weight } \\
+ \text { Drainage density rank } \times \text { weight }+ \text { Slope rank } \times \text { weight } \\
+ \text { Land use rank } \times \text { weight }) .
\end{gathered}
$$

\section{Result and Discussion}

\subsection{Geology}

The study area is characterized by the presence of Granite, Granofire and Dhanjori group of Precambrian age (Figure 2), the main rock type granite and Granofire. Percentage of Granite and Granofire is $84 \%$ and $9 \%$ respectively (Figure 3). These rocks lack Primary porosity. Ground water occurrence is restricted to weathered and fractured zone. Ground water occurs in unconfined and confined aquifer condition.

\subsection{Geomorphological Map}

Geomorphology is the study of landforms, it included study of the geology and evolution of landforms. By using of SRTM DEM, IRS LISS-III data and survey of India toposheet all the geomorphology units were extracted. The Bamanghaty 
Subdivision has seven types of geomorphological unit: structural hill, denudational hill, residual hill, pediments, shallow weathered pediplain, intermontane valley and plateau, which detail is given in Figure 4, area is given in Figure 5.

\subsection{Denudational Hills}

Denudation incorporates the mechanical, biological and chemical processes of wearing down, weathering and mass wasting. Denudation can involve the subtraction of both solid particles and dissolved material. These include sub-processes of cry-fracture, insulations weathering, slaking, salt weathering, bio-turbation and anthropogenic impacts. They are exposed as a group of massive hills with resistant rock bodies and smoothed summits and are formed due to differential erosion and weathering. Denudational hills are identified in the satellite imagery by their Dull red tone, coarse texture irregular shape. They appear as dark Eme-

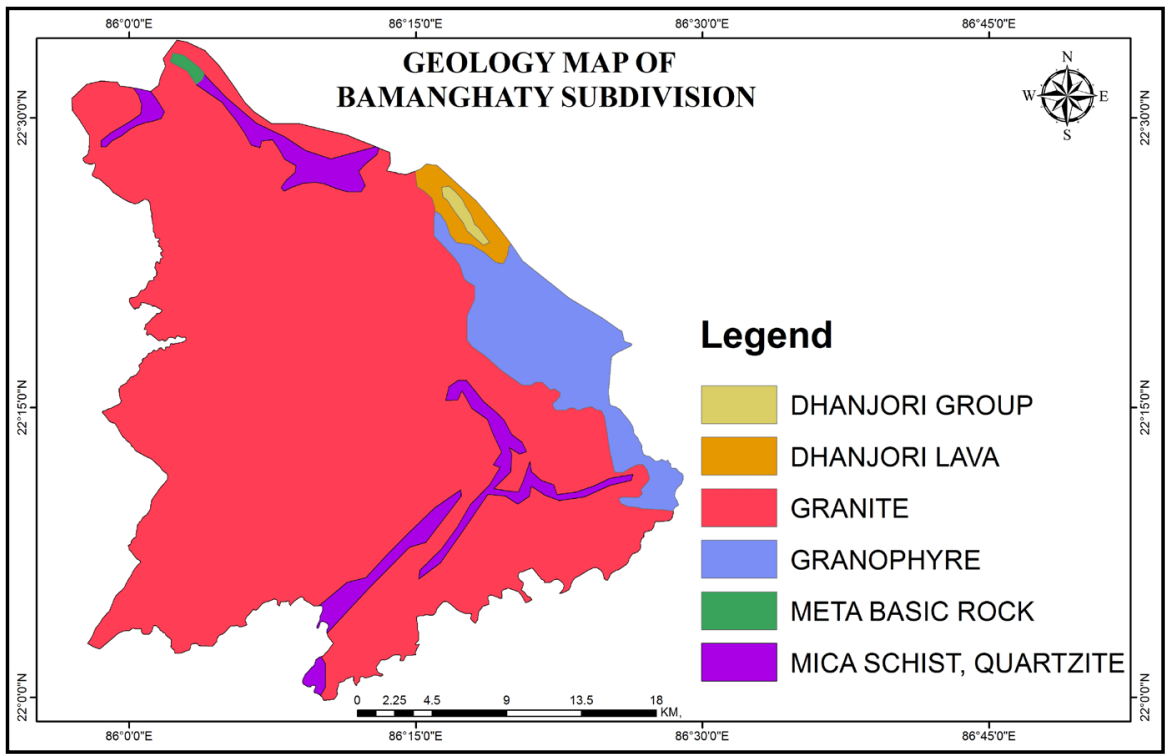

Figure 2. Geology map of Bamanghaty subdivision.

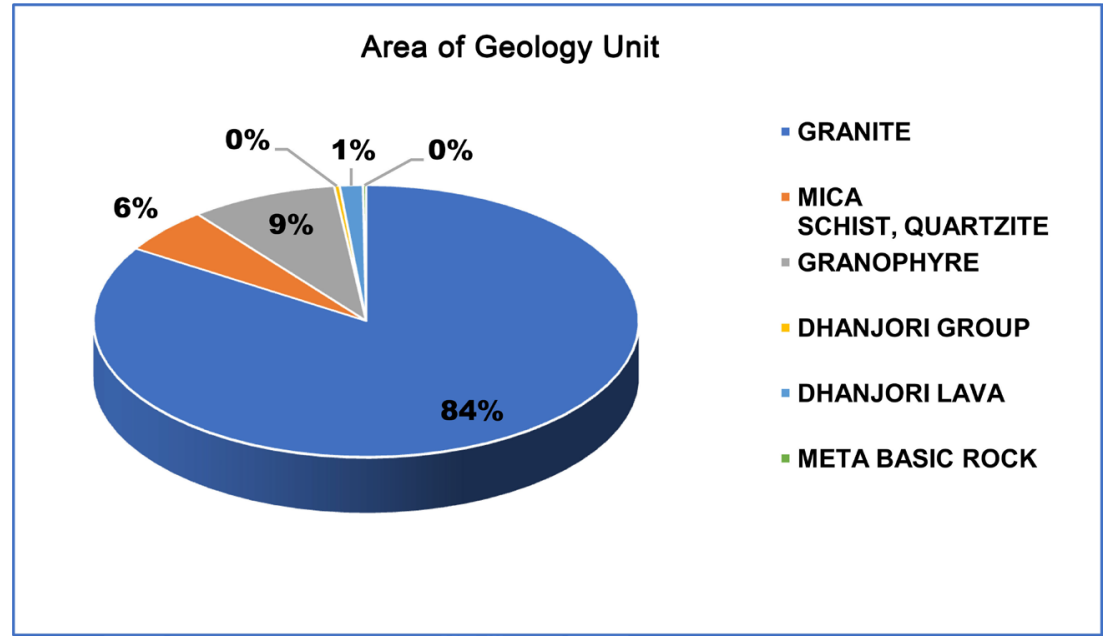

Figure 3. Area of geological unit of Bamanghaty subdivision. 


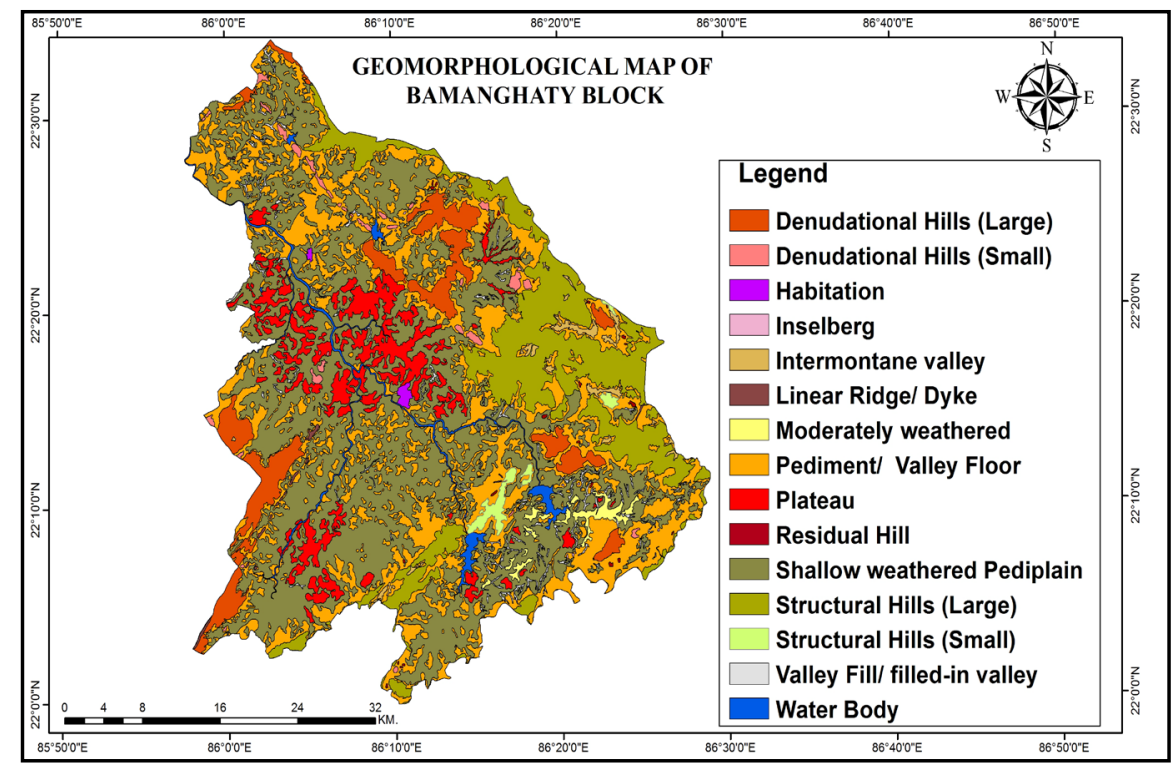

Figure 4. Geomorphology map of Bamanghaty subdivision.

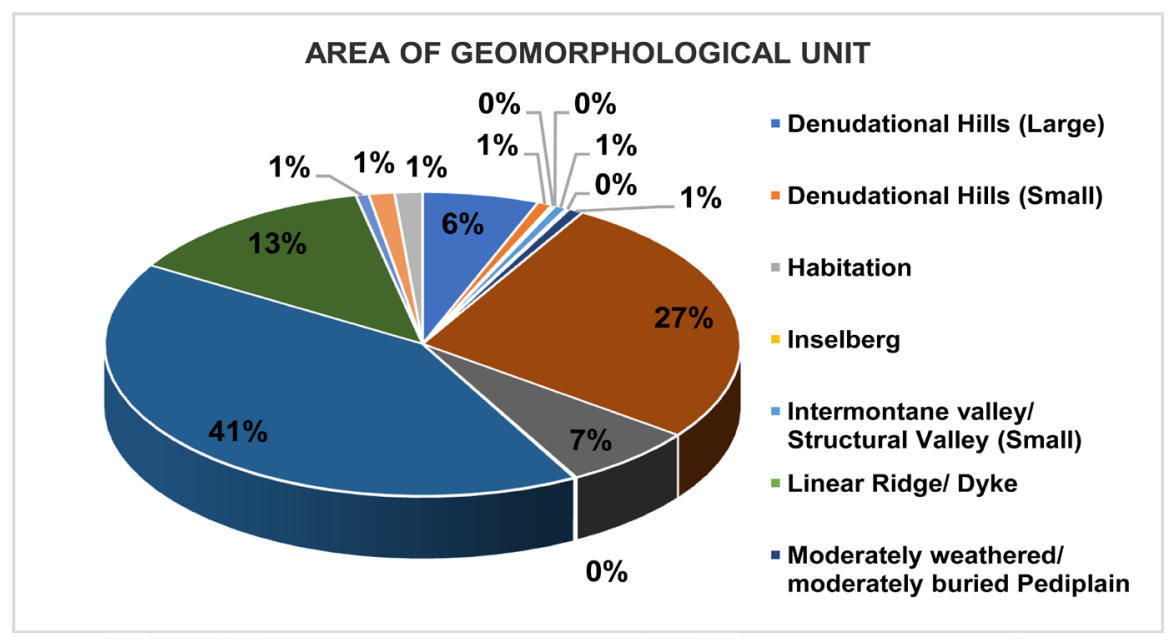

Figure 5. Area of geomorphology unit of Bamanghaty subdivision.

rald in colour in the satellite imagery as well as our Geomorphological map. This landform in general, Weathered granite, dendritic drainage, moderate to steep slopes, sparse vegetation. Denudational hills due to their relief acts as breaking point boundary also. The groundwater impending of this landform in general is very poor. The denudational hills are commonly found in the Jamda. Bijatala, Bahalda estern portion, Western portion of Kusumi and Bisoi blocks $0.6 \%$ of denudational hill is covered in Bamanghaty subdivision.

\subsection{Habitation}

In geography, statistics and archaeology arrangement, neighborhood or occupied place is a community in which individuals live. A defrayal unadventurously includes its constructed amenities such as pathway, blockage, territory of the Bamanghaty subdivisional area, systems, perimeter banks and ditches, ponds, 
parks and woods, wind and water mills, manor houses, moats and churches. The Bamanghaty subdivision have total household is 7334 and total population 495,005. The Hindu, Muslim, christen, Janna and Buddha habitation are situated in the Bamanghaty subdivision, Mayurbhanj District of Odisha.

\subsection{Pediplains}

Pediplains are usually formed in arid or semi-arid climates and may have a thin facing of sediments. It is a concept in geomorphology that express an extensive plain twisted by the coalescence of pediments. The processes through which pediplains forms is known as pediplanation. Pediplains, broad, relatively flat rock facade formed by the amalgamation of numerous pediments. It is thought that such an exterior is most suited to deal with the exonerate of short-lived hammering cloudbursts characterizing arid and semi-arid regions. The entire area of the Bamanghaty subdivision has been the pediplains geomorphic characteristics. The pediplains showing in the pale pink colour.

\subsection{Plateau}

Plateaus can be formed by a number of processes, including upwelling of volcanic magma, extrusion of lava, and erosion by water and glaciers. The land form characteristics of Plateau is Table land shaped hill with flat surface at the top with sloping sides. They appear as Dark red tone coarse texture irregular shape in satellite imagery. The plateaus are located in the Bahalda, Kusumi, Rairangpur and Jamda blocks. The plateau has Granite and Gneissic Rocks formation.

\subsection{Structural Hills}

These are group of curvilinear folded hill ranges. These units are intensely folded, jointed and fractured. They act as runoff zone with poor recharge condition. They appear as Dark red tone coarse texture irregular shape and their land description is Linear to arcuate hills, dissected, granitic rocks mostly dendritic drainage, jointed ridges, average height $300 \mathrm{~m}$. strong to very steep slopes A large numbers of structural hills has been positioned on the Bisoi, Western Rairangpur block, Bahalda and Bijatola Block of Bamanghaty Subdivision

\subsection{Pediment}

It is a gently sloping rocky surface with or without a thin veneer of soil cover. The area under this unit is generally considered to be the poor groundwater potential zone. The presence of fractures represented by lineaments over pediment indicate some groundwater potentiality. They appear as Light red to red tone, moderate to fine texture in satellite imagery. Total 512 square KM area cover in Bamanghaty Subdivision.

\subsection{Intermontane Valley}

These are almost flat valleys surrounded by hills all around and mostly observed in Bijatola, Kusumi and Rairangpur Block. Owing to their position, these units 
are highly favorable loci for groundwater occurrence and important for dug well. They appear as Green-bluish mixed tone moderate to fine texture in satellite imagery.

\subsection{Inselbergs}

These are isolated hills made of up quartzite of Deogarh Group with limited areal extension surrounded by plain land and mostly observed in Bisoi Bijatola, and Bahalda Block. Groundwater potential is very poor in these units.

The image and physical characteristics of different land form in study area is given in the (Table 1).

\section{Lineament Density Map}

To establish the lineament density in the study area the total study area is subdivided in a number of grids of measurement $1 \mathrm{~km} \times 1 \mathrm{~km}$. Density of the lineaments of a solitary grid is obtained beginning the standards of the total measurement lengthwise of the lineaments in a particular network. In the present study, the north west and south-eastern part of the study area the lineament density is more, low lineament is found in northern and southern part the of the study area. The Bisoi, Kusumi and Bijatola block have the higher lineament density of the Bamanghaty subdivision of Mayurbhanj district of Odisha the low lineament density has been found in the northern portion of the Bamanghaty subdivision, Odisha, such as Tiring and Bahalda blocks. Medium lineament density has been found in the Rairangpur and Jamda blocks (Figure 6).

Table 1. Image and physical characteristics of different land form in the study area.

\begin{tabular}{|c|c|c|c|}
\hline Geomorphic unit & Image elements & Landform characteristics (Ground observation) & Area in sq. km. \\
\hline Structural hills & $\begin{array}{l}\text { Dark red tone coarse texture } \\
\text { irregular shape }\end{array}$ & $\begin{array}{l}\text { Linear to arcuate hills, dissected, granitic rocks mostly dendritic drainage, } \\
\text { jointed ridges, average height } 300 \mathrm{~m} \text {. strong to very steep slopes }\end{array}$ & 260.234177 \\
\hline Denudational hills & $\begin{array}{l}\text { Dull red tone, coarse texture } \\
\text { irregular shape }\end{array}$ & $\begin{array}{l}\text { Weathered granite, dendritic drainage, moderate to steep slopes, sparse } \\
\text { vegetation }\end{array}$ & 127.2507 \\
\hline Residual hills & $\begin{array}{l}\text { Dark grey tone, coarse texture } \\
\text { shape and size-irregular and } \\
\text { rounded }\end{array}$ & $\begin{array}{l}\text { Erosional surfaces, isolated mounds which have undergone the process of } \\
\text { denudation, Steep slopes, radial drainage act as runoff zones }\end{array}$ & 131.443052 \\
\hline Pediments & $\begin{array}{l}\text { Light red to red tone, } \\
\text { moderate to fine texture }\end{array}$ & $\begin{array}{l}\text { Gentle to moderate slopes, devoid of vegetation with various depths of } \\
\text { weathering material, shallow sediment covers rocky and gravely surfaces, } \\
\text { dendritic to sub-dendritic drainage, mostly vegetated or cultivated lying at } \\
\text { foot hills }\end{array}$ & 512.468246 \\
\hline $\begin{array}{l}\text { Shallow weathered } \\
\text { pediplains }\end{array}$ & $\begin{array}{l}\text { Green-bluish mixed tone } \\
\text { moderate to fine texture }\end{array}$ & $\begin{array}{l}\text { These units are characterized by the presence of relatively thicker weathered } \\
\text { material. The thickness of the weathered material is (up to } 5 \mathrm{~m} \text {. These } \\
\text { hydrogeomorphic units are developed mostly upon Mayurbhanj Granite }\end{array}$ & 793.759105 \\
\hline $\begin{array}{l}\text { Intermontane } \\
\text { valley }\end{array}$ & $\begin{array}{l}\text { Green-bluish mixed tone } \\
\text { moderate to fine texture }\end{array}$ & $\begin{array}{l}\text { A linear or curvilinear depression valley within the hills, filled with colluvial } \\
\text { deposits of IOG sediments }\end{array}$ & 0.981388 \\
\hline Plateau & $\begin{array}{l}\text { Dark red tone coarse texture } \\
\text { irregular shape }\end{array}$ & Table land shaped hill with flat surface at the top with sloping sides & 129.419945 \\
\hline
\end{tabular}




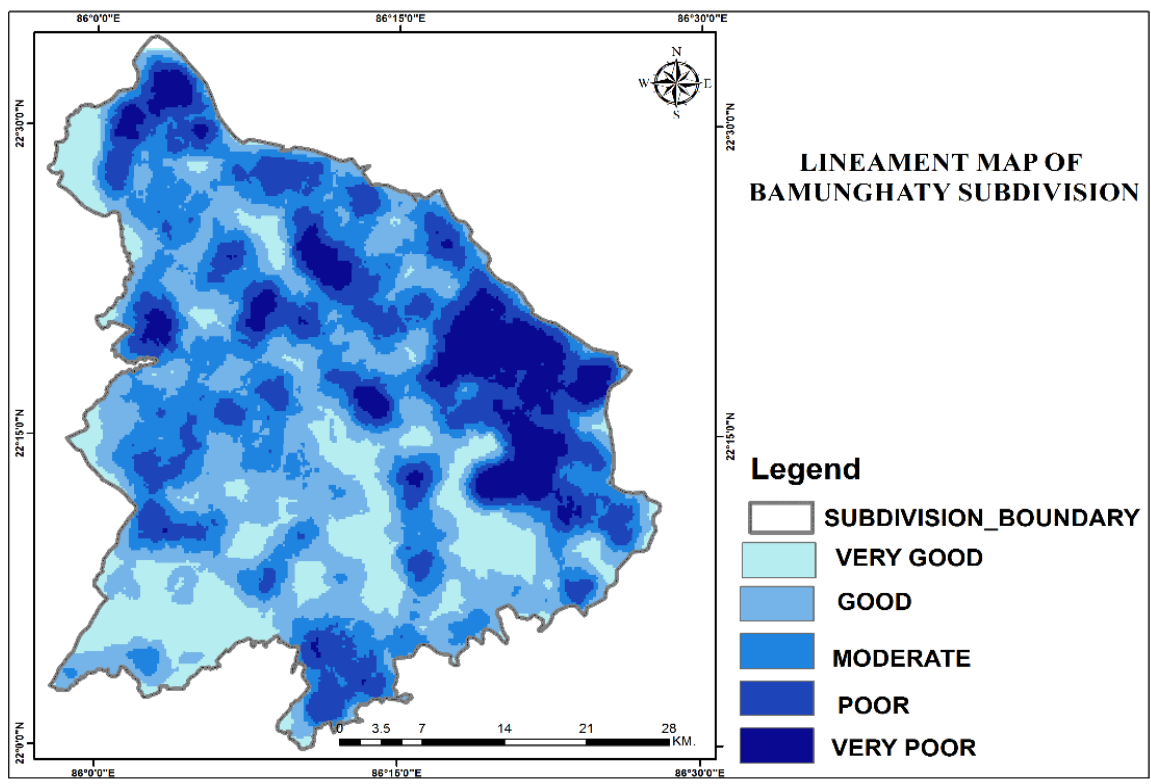

Figure 6. Lineament density map of Bamanghaty subdivision.

\section{Slope Map}

Slope is one of the most significant parameters for groundwater investigation. Slope immovability analyses carried out in terms of precious anxiety necessitate an understanding of the distribution of pore-water pressures in a slope. The slope varies from 000-42. On the basis of degree of slope, the study area has been classified into four slope classes. The area having Zero to three degree falls into very high for ground water storage categories because of the maximum nearly flat terrain and relatively very high infiltrations rate it's also known the gentle slope. The areas with three degrees to nine-degree slopes are considered as good as due to slightly undulating and quite flat topography its known as the moderate slope. The area having a slope of Nine degree to Seventeen Degree caused poor undulating semi flat relatively high-moderate runoff and low-moderate infiltrations the categories are high-moderate slope it's also known as the steep slope and the area having a slope of Seventeen Degree to Forty-Two Degree caused comparatively very high runoff and very-very low infiltrations it's also known as the muscularly steep slope and it is poor ground water potential (Figure 7).

\section{Drainage Density}

In the geomorphology, the drainage System is the river system. A network of channels and drainage constructed on exceptionally wetland. It is the key ingredient of a drainage system and consist of amendable protective and conducting network with networks with drainage outlets, manholes, overalls, chutes, bridges and others such structure. The determination of good superiority drainage network can be extracted from altimetry grids with high or at slightest medium resolution. They can be used for studies in small and large watersheds. Through the DEM Image we can made a drainage network map for the drainage density and 


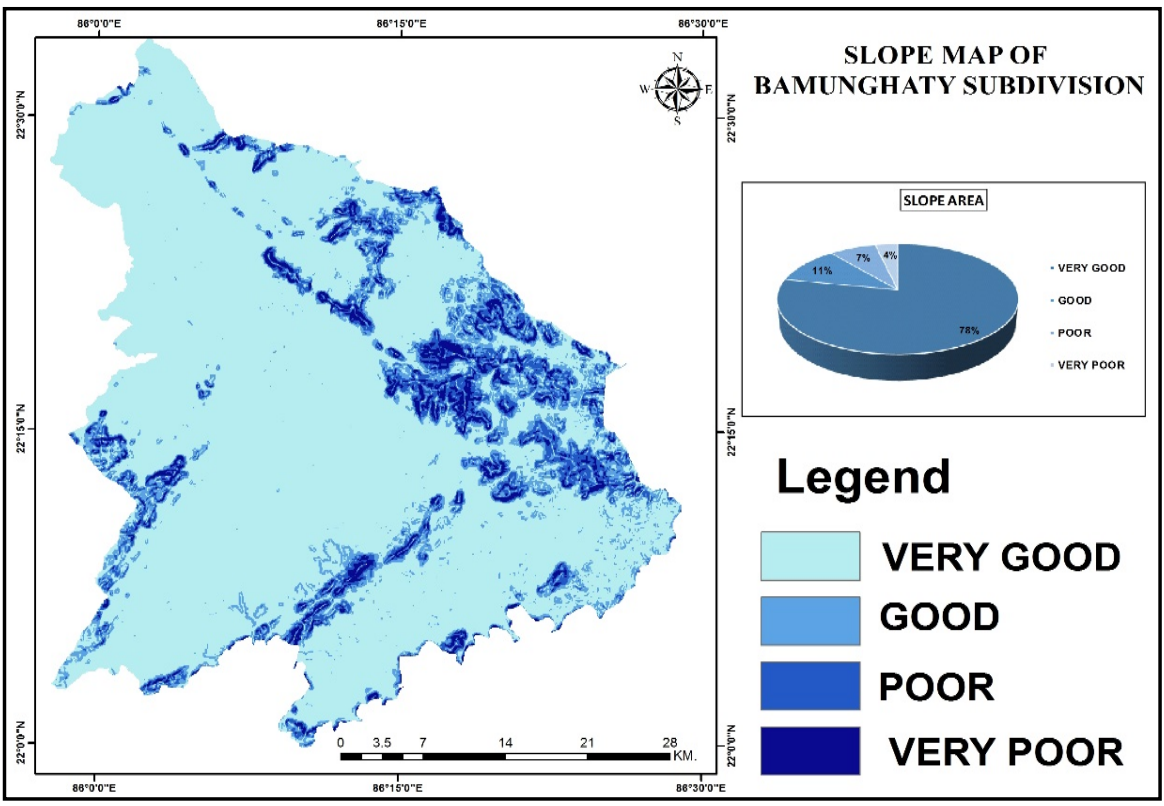

Figure 7. Slope map of Bamanghaty subdivision.

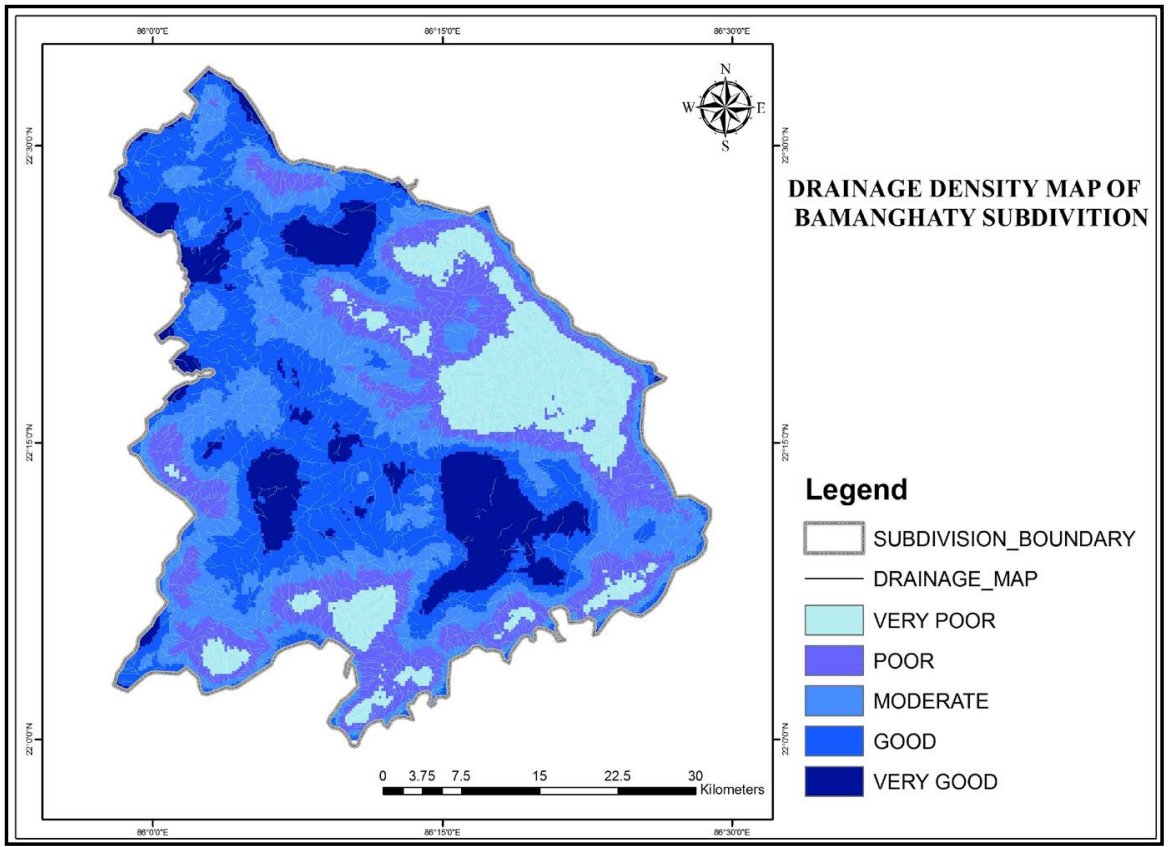

Figure 8. Drainage density Map of Bamanghaty subdivision.

drainage buffer map invent. The drainage network is basis information for just beginning applications connecting surface and underground water resources. Dendric Drainage pattern has been initiate in the Rairangpur-Bahalda border region. Many more drainage network has positioned in the whole Bamanghati Subdivision. Maximum drainage Network are Dendric drainage type. High drainage density is located in the Rairangpur and Bahalda region. The South east Kusumi is the others area of high drainage density region. The very low drainage density is situated in the Bisoi, Kusumi, Bijatola Border and North east Bahalda 
(Figure 8).

\section{Weight Assignment and Geospatial Modeling}

Suitable weights were assigned to the five themes according to their impact in groundwater occurrence in the Bamanghaty Subdivision. The normalized weights of the individual themes and their different features were obtained. The weights assigned to different themes are presented in Table 2. After deriving the

Table 2. Ranks assigned to different parameters used for overlay.

\begin{tabular}{|c|c|c|c|c|}
\hline Sl No & Parameters & Classes & Feature score & Map weight \\
\hline \multirow{11}{*}{1} & \multirow{11}{*}{ Geomorphology } & Denudational hills (Large) & 1 & \multirow{11}{*}{30} \\
\hline & & Denudational hills (Small) & 1 & \\
\hline & & Habitation & 1 & \\
\hline & & Intermontane valley/Structural valley (Small) & 8 & \\
\hline & & Pediment/Valley floor & 2 & \\
\hline & & Pediplain & 7 & \\
\hline & & Plateau & 2 & \\
\hline & & Shallow weathered/shallow buried pediplain & 6 & \\
\hline & & Structural hills (Large) & 2 & \\
\hline & & Valley fill/filled-in valley & 8 & \\
\hline & & Water body & 10 & \\
\hline \multirow{4}{*}{2} & \multirow{4}{*}{$\begin{array}{l}\text { Slope classes } \\
\text { (Degree) }\end{array}$} & 0 to 3 & 8 & \multirow{4}{*}{15} \\
\hline & & 3 to 9 & 6 & \\
\hline & & 9 to17 & 3 & \\
\hline & & $17-42$ & 1 & \\
\hline \multirow{5}{*}{3} & \multirow{5}{*}{$\begin{array}{l}\text { Drainage density } \\
\qquad\left(\mathrm{Km} / \mathrm{Km}^{2}\right)\end{array}$} & $0-93$ & 9 & \multirow{5}{*}{15} \\
\hline & & $93-186$ & 7 & \\
\hline & & $186-280$ & 6 & \\
\hline & & $280-373$ & 4 & \\
\hline & & $373-467$ & 3 & \\
\hline \multirow{5}{*}{4} & \multirow{5}{*}{$\begin{array}{l}\text { Lineament density } \\
\qquad\left(\mathrm{Km} / \mathrm{Km}^{2}\right)\end{array}$} & $0-122$ & 2 & \multirow{5}{*}{20} \\
\hline & & $122-244$ & 3 & \\
\hline & & $244-367$ & 6 & \\
\hline & & $367-489$ & 8 & \\
\hline & & $489-612$ & 9 & \\
\hline \multirow{6}{*}{5} & \multirow{6}{*}{ Geology } & Dhanjori group & 7 & \multirow{6}{*}{20} \\
\hline & & Dhanjori lava & 4 & \\
\hline & & Granite & 5 & \\
\hline & & Granofire & 5 & \\
\hline & & Meta basic rock & 4 & \\
\hline & & Mica schist & 3 & \\
\hline
\end{tabular}




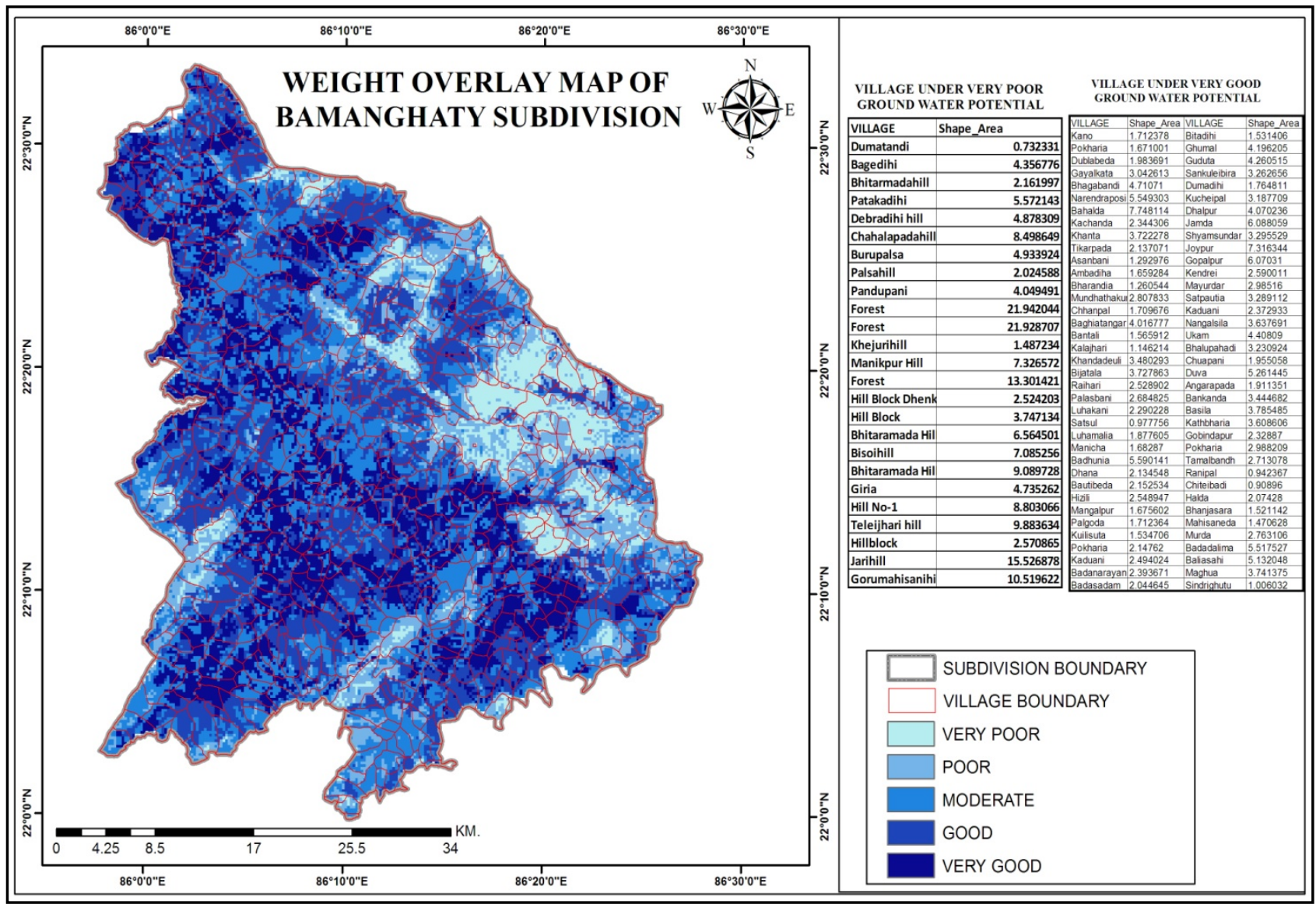

Figure 9. Weight overlay Map of Bamanghaty subdivision.

normal weights of all the thematic maps are converted into raster format and superimposed by weighted overlay method and all the thematic layers were integrated with one another using spatial analysis of Arc-GIS software to delineate groundwater potential zones in the study area. The final integrated layer was divided into five classes, i.e. "very good", "good" "moderate", "poor" and "very poor" in order to delineate groundwater potential zones (Figure 9).

\section{Conclusion}

Delineation of groundwater potential zones in Bamanghaty subdivision of Mayurbhanj district using remote sensing and GIS techniques is found efficient to minimize the time, labour and money and thereby enables quick decision-making for sustainable water resources management. Satellite imageries, topographic maps data were used to prepare the thematic layers of Geology, Geomorphology, lineament density, drainage density, and slope. All The thematic layers are assigned proper weight age with respect to ground water potential and then integrated in the GIS environment to prepare the groundwater potential zone map of the study area. According to the groundwater potential zone map, the block is categorized into five different zones, namely "very good", "good", "moderate", "poor", and "very poor". This is a practical method for the exploration and ex- 
ploitation of groundwater potential zones for the domestic and irrigational purposes. Remote Sensing and GIS technique will certainly enable us to develop and manage precious groundwater resources in a real sustainable and environment-friendly way. The results of the present study can serve as easy prospective guides for assessment, planning, management, administration, sustainable utilization of groundwater in near feature.

\section{References}

[1] Roy, A.K. (1991) Hydromorphogeology for Groundwater Targeting and Development in Dehradun Valley, UP. In: Gupta, P.N. and Roy, A.K., Eds., Mountain Resource Management and Remote Sensing, Surya Publications, Dehradun.

[2] Greenbaum, D. (1992) Structural Influences on the Occurrence of Groundwater in SE Zimbabwe. In: Wright, E.P. and Burges, W.G., Hydrology of Crystalline Basement Aquifers in Africa, Geological Society Publishing House, Bath, 77-85. https://doi.org/10.1144/GSL.SP.1992.066.01.04

[3] Mukherjee, S. (1996) Targeting Saline Aquifer by Remote Sensing and Geophysical Methods in a Part of Hamirpur-Kanpur, India. Hydrology Journal, 19, 53-64.

[4] Krishnamurthy, J. and Srinivas, G. (1995) Role of Geological and Geomorphological Factors in Groundwater Exploration-A Study through Remote Sensing Techniques. International Journal of Remote Sensing, 16, 2925-2618. https://doi.org/10.1080/01431169508954579

[5] Choudhury, P.R. (1999) Integrated Remote Sensing and GIS Techniques for Groundwater Studies in Part of Betwa Basin. Ph.D. Thesis, University of Roorkee, India.

[6] Singh, A.K. and Prakash, S.R. (2002) An Integrated Approach of Remote Sensing, Geophysics and GIS to Evaluation of Groundwater Potentiality of Ojhala Sub-Watershed, Mirjapur District, UP, India. In: Asian Conference on GIS, GPS, Aerial Photography and Remote Sensing, Bangkok-Thailand.

[7] NRSA (2008) Groundwater Prospect Mapping Using Remote Sensing and GIS, Rajiv Gandhi National Drinking Water Mission Project Manual. National Remote Sensing Agency, Hyderabad.

[8] Avtar, R., Singh, C.K., Shashtri, S., Singh, A. and Mukherjee, S. (2010) Identification and Analysis of Groundwater Potential Zones in Ken-Betwa river Linking Area Using Remote Sensing and Geographic Information System. Geocarto International., 25, 379-396. https://doi.org/10.1080/10106041003731318

[9] Chowdhury, A., Jha, M.K. and Chowdary, V.M. (2010) Delineation of Groundwater Recharge Zones and Identification of Artificial Recharge Sites in West Medinipur District, West Bengal, Using RS, GIS and MCDM Techniques. Environmental Earth Science, 59, 1209-1222. https://doi.org/10.1007/s12665-009-0110-9

[10] Rashid, M., Lone, M. and Ahmed, S. (2011) Integrating Geospatial and Ground Geophysical Information as Guidelines for Groundwater Potential Zones in Hard Rock Terrains of South India. Environmental Monitoring Assessment, 184, 4829-4839. https://doi.org/10.1007/s10661-011-2305-2

[11] Ibrahim-Bathis, K. and Ahmed, S.A. (2016) Geospatial Technology for Delineating Groundwater Potential Zones in Doddahalla Watershed of Chitradurga District, India. The Egyptian Journal of Remote Sensing and Space Sciences, 19, 223-224. https://doi.org/10.1016/j.ejrs.2016.06.002 
[12] Nag, S.K, Anindita Lahiri. (2011) Integrated Approach Using Remote Sensing and GIS Techniques for Delineating Groundwater Potential Zones in Dwarakeswar Watershed, Bankura Distict, West Bengal. International Journal of Geomatics and Geosciences, 2, 430-442.

[13] Basavaraj H. and Nijagunappa, R. (2011) Identification of Groundwater Potential Zone Using Geoinformatics in Ghataprabha Basin, North Karnataka, India. International Journal of Geomatics and Geosciences, 2, 91-109.

[14] Krishnamurthy, J., Venkatesa Kumar, N., Jayaraman, V. and Manuvel, M. (1996) An Approach to Demarcate Groundwater Potential Zones through Remote Sensing and a Geographical Information System. International Journal of Remote Sensing 17, 1867-1884. https://doi.org/10.1080/01431169608948744 